\title{
The Effect of Cooperative Learning Group Investigation Type In Science With an Outdoor Learning System Approach on Problem Solving Skills and the Mastery of Concepts in Junior High School Student
}

\author{
Fitri Nur Aini ${ }^{*}$ \\ ${ }^{1}$ Science Education, Faculty of Mathematics and Natural Sciences, Universitas Negeri Yogyakarta \\ Corresponding Author. Email: fitrinuraini176@gmail.com
}

\section{Keywords: group investigation, outdoor learning system, problem solving, the mastery of concepts}

\begin{abstract}
The research aimed to know (1) the effect of the implementation cooperative learning group investigation type with an outdoor learning system on problem-solving skills, (2) the effect of the implementation cooperative learning group investigation type with an outdoor learning system on the mastery of concepts, and (3) the simultaneous effect of cooperative learning group investigation type with an outdoor learning system on problem-solving skills and the mastery of concepts. This research was a quasi-experimental research with a nonequivalent pretest-posttest control group design. The population was the seventh-grade students of SMP N 2 Tempel. The sample selection technique used the purposive sampling technique; class of VIII C played as an experimental class and VIII D played as control class. The instruments on data collection used problem-solving tests and mastery of concept tests. The parametric test used in this research which was an independent sample ttest followed by effect size, and MANOVA. The results showed: (1) there was an effect of the implementation cooperative learning group investigation type with an outdoor learning system on problem-solving skills with poor category, (2) there was an effect of the implementation cooperative learning group investigation type with an outdoor learning system on the mastery of concepts with high effects, and (3) there was a simultaneous effect of cooperative learning group investigation type with an outdoor learning system on problem-solving skills and the mastery of concepts.
\end{abstract}

C2020 JSER. Yogyakarta State University

\section{INTRODUCTION}

In this era of globalization, education is seen as an identity for a country, which education plays a role as the main indicator in the development of a nation. Education contains good and noble values which are very proper to be developed in all aspects of life. Therefore, the state must strive for equal distribution of education to all regions in Indonesia, as stated in the preamble to the 1945 Constitution.

Law number 20 of 2003 suggests the important thing in the education process is the learning process that occurs in school. The learning process in schools may determine by several things, such as the teaching model implemented by the teacher. The model or method of teaching implemented by the teacher is a different one and another. The teacher-centered learning model focuses on the ability of teachers to deliver the learning material in front of the class. Meanwhile, student-centered learning focuses on how students acquire the learning material.

Based on the results of observations at SMP Negeri 2 Tempel, Sleman regency, during the PLP activity, shown that teachers of science used teacher-centered learning, which is the learning mostly dominated by teachers. On the other hand, students pay only attention and listen to the explanations delivered by the teacher. In fact, it is still not meet the Curriculum 2013, which requires teachers to implement student-centered learning.

Law number 20 of 2003 also states that the success of education is determined by the achievement of educational goals. Educational goals determine student learning outcomes, which, based on the high or low student learning outcomes. Learning outcomes are obtained from assessments 
made by a teacher through learning evaluation activities, such as daily tests.

Cognitive learning outcomes or concept mastery at SMP N 2 Tempel are classified as low. Another supported thing is, the score of PAS is below the KKM score. The mean for PAS I seventhgrade on SMP N 2 Tempel is 51, with 70 on KKM (Completeness Minimum Criteria) score.

Group investigation learning trains students to think analytically, critically, creatively, reflectively, and productively. With this learning, students' abilities, both cognitive and psychomotor, can be more developed (Dewi, 2012, p.70). Slavin (2005, p.215) states that this model makes students able to interpret, evaluate observations, and identify what needs to be known and learned to master concepts and solve the problems through investigation. Moreover, those aim to train students to have knowledge with good group cooperation and solve the problems.

This type of group investigation learning that emphasizes the participation and activities of students in inviting students to think scientifically and solving problems is very appropriate for learning science. Supported by the Curriculum 2013 which states the importance of problem-solving abilities, as seen in the basic competences of science learning which states that "students are expected to master the concepts and principles of science, and interrelation and are applied in solving problems in life" (Permendikbud No. 21 of 2016). However, the students' ability to solve problems of science at SMP N 2 Tempel is still low. This conclusion is drawn from the results of observations during experimental activities and class discussions that the ability of students to state problems, state hypotheses, and experiment variables is still low as they only focus on what the teacher says.

An outdoor learning approach is an approach taken by the teacher, where the teacher invites students to study outside the classroom, which aims to see the events directly in the field and used as a learning resource (Vera, 2012: 17). But, discussing on the reference source chosen by the teacher for teaching, the research showed that 55\% of science teachers choose textbooks as the first reference, $30 \%$ from the internet, $13 \%$ from supporting books, $1 \%$ from journals, and $1 \%$ from newspapers/magazines (Insani, 2015).

Based on the background, the artilce conducted a research with the title "The Effect of Cooperative Learning Group Investigation Type in Science with an Outdoor Learning System Approach on Problem Solving Skills and the Mastery of Concepts in Junior High School Student."

\section{METHOD}

\section{Research Type}

This study used quasi-experimental research with a nonequivalent pretest-posttest control group design. This study examined the effect of the independent variable (the learning model of cooperative learning group investigation type with the approach of outdoor learning system) on the dependent variable (problem-solving skills and concept mastery).

\section{Time and Place of Research}

The research was conducted at SMP Negeri 2 Tempel in February 2020.

\section{Population / Research Sample}

The population was all students of seventhgrade at SMP N 2 Tempel. The sampling technique used a purposive sampling technique. The criteria made were the score of PAS I, the schedule of learning, the number of students, and both classes had carried out daily tests regarding the previous material at the time of the research. The research used two classes, namely class VII C played as the experimental group, and class VII D played as the control group.

\section{Procedure}

This research used the design "Non-equivalent Pretest-Posttest Control Group Design." The research design is presented in table 1:

Table 1. Research Design

\begin{tabular}{lccc}
\hline \multicolumn{1}{c}{ Group } & Pretest & Treatment & Posttest \\
\hline Experiment & $\mathrm{O}_{1} \mathrm{~A} \mathrm{O}_{1} \mathrm{~B}$ & $\mathrm{X}_{1}$ & $\mathrm{O}_{2} \mathrm{~A} \mathrm{O}_{2} \mathrm{~B}$ \\
Control & $\mathrm{O}_{3} \mathrm{~A} \mathrm{O}_{3} \mathrm{~B}$ & $\mathrm{X}_{2}$ & $\mathrm{O}_{4} \mathrm{~A} \mathrm{O}_{4} \mathrm{~B}$ \\
\hline
\end{tabular}

Where :

$\mathrm{X}_{1}$ : The learning model of cooperative learning group investigation type with the approach of outdoor learning system

$\mathrm{X}_{2}$ : Problem-based learning model (PBL)

$\mathrm{O}_{1} \mathrm{~A}$ : Initial ability to mastery the concept in the experimental class

$\mathrm{O}_{1} \mathrm{~B}$ : problem-solving skills in the experimental class

$\mathrm{O}_{2} \mathrm{~A}$ : The final ability of mastery of concepts in the experimental class

$\mathrm{O}_{2} \mathrm{~B}$ : The final ability of problem-solving skills in the experimental class

$\mathrm{O}_{3} \mathrm{~A}$ : Initial ability to mastery the concept in the control class 
$\mathrm{O}_{3} \mathrm{~B} \quad$ : Initial ability of problem-solving skills in the control class

$\mathrm{O}_{4} \mathrm{~A}$ : The final ability of mastery of concepts in the control class

$\mathrm{O}_{4} \mathrm{~B} \quad$ : The final ability of problem-solving skills in the control class

Data, Instruments, and Data Collection Techniques

The data collection technique used a test. The instrument on data collection was a test of problemsolving skills and mastery of the concept, consisting of 20 items multiple-choice and seven items of the essay.

\section{Data analysis technique}

The data analysis techniques consisted of $\mathrm{N}$ Gain Scores; hypothesis prerequisite tests including normality test, homogeneity test (variant and covariance) and correlation test; hypothesis testing using the Independent sample t-test and MANOVA; and Effect size.

$\mathrm{N}$-Gain Scores calculate using the following formula:

N-Gain Score $(\mathrm{g})=\frac{\text { Posttest }- \text { Pretest }}{100-\text { Pretest }}$

Table 2. Criteria of N-Gain Score

\begin{tabular}{|c|c|}
\hline $\boldsymbol{N}$-Gain Score & Interpretation \\
\hline$g<0.00$ & Decreasing \\
\hline $\mathrm{g}=0.00$ & Constant \\
\hline $0<g<0.3$ & Low \\
\hline $0.3 \leq g \leq 0.7$ & Moderate \\
\hline$g>0.7$ & High \\
\hline
\end{tabular}

Cohen's equation was used to calculate the Cohen's d effect size :

$$
d=\frac{\bar{X}_{t}-\bar{X}_{c}}{\text { Spooted }}
$$

Where:

$$
\begin{array}{ll}
d & =\text { cohen's } d \text { effect size } \\
\bar{X}_{t} & =\text { mean treatment condition } \\
\bar{X}_{c} & =\text { mean control condition } \\
\text { Spooted } & =\text { combined standard deviation (Sgab) }
\end{array}
$$

The following formula was used to callculate the Spooted (Sgab):

$$
S g a b=\sqrt{\frac{\left(n_{1}-1\right) s d_{1}^{2}+\left(n_{2}-1\right) s d_{2}^{2}}{n_{1}+n_{2}-2}}
$$

Where:

$S g a b=$ Combined standard deviation $n_{1} \quad=$ number of students in experiment class

$n_{2} \quad=$ number of student in control class

$s d_{1}^{2}=$ varians in experiment class

$s d_{2}^{2}=$ varians in control class

Criteria in Table 3 were used to determine the interpretation value of Cohen's d effect size:

Table 2. Interpretation of Effect Size

$\begin{array}{cc}\text { Effect size } & \text { Interpretation } \\ \mathrm{d}<0,2 & \text { Very Low } \\ 0,2 \leq \mathrm{d}<0,5 & \text { Low } \\ 0,5 \leq \mathrm{d}<0,7 & \text { Moderate } \\ \mathrm{d} \geq 0,7 & \text { High }\end{array}$

\section{RESULT}

The Effect of Cooperative Learning Group Investigation Type with Outdoor Learning System Approach on Students' Problem Solving Skills

Measurement of students' problem-solving skills was seen from the results of the pretestposttest on questions instrument on problem-solving abilities. The questions consisted of 7 items. Then, it obtained the mean of pretest-posttest on problemsolving skills, both in the experimental class and control class, which is presented in figure 1:

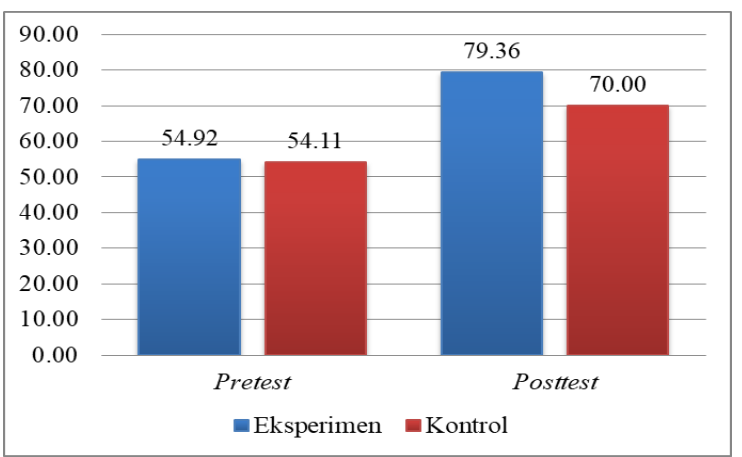

Figure 1. Bar Diagram of Problem Solving skills Score

The questions of problem-solving skills were made based on several indicators. Figure 2 is the diagram of the mean on each indicator for both the experimental and control class: 


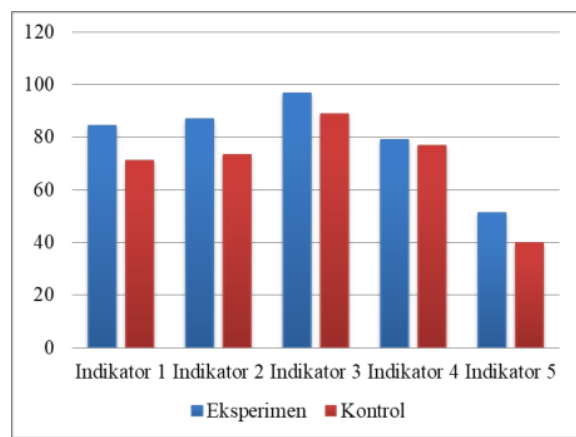

Figure 2. Bar Chart of Mean Data of Problem Solving Skills on Each Indicator

The diagrams showed that the posttest score in the experimental class on problem-solving ability was higher than the control class. The differences were relatively significant. The results were in line with Subekti (2013, p.211) concluded that problemsolving skills, communication skills, and learning motivation of students increased by implementing the cooperative learning group investigation type.

The pretest-posttest score that was analyzed using the Independent T-Test showed 0.017 or Sig (21-tailed) $<1 / 2 \alpha(\alpha=0.05)$. These results indicated, that there was an effect on the learning model on problem-solving skills. The calculation of Cohen's d effect size showed a score of 0.225 . This score showed the effect of implementation included in the low category of $14.7 \%$.

By implementing the learning model, the students were invited to understand a problem, by finding as much information as possible, related to the provided problem (Slavin, 2005, p.215). In this study, this information may obtain from the environment through an outdoor learning system approach. Then, the information is discussed to formulate the problem so that the students can choose the right strategy to solve the problem. Kellert (2002) states that students could gain problem-solving ability by implementing outdoor learning.

Research by Febria (2019) states that the student's problem solving who treated with the cooperative learning group investigation type was higher than traditional learning. Besides, research by Sastiawan, et al. (2019) states that problem-solving skills can be improved using environment-based learning or outdoor learning systems.

The Effect of Cooperative Learning Group Investigation Type with Outdoor Learning System Approach on Students' Mastery of the Concept

In this study, the mastery of the conceptual ability was measured using a test instrument. The questions consisted of 20 items multiple-choice questions and seven items of the essay. The analysis results of the mean on students' mastery of the concept are presented in figure 3 :

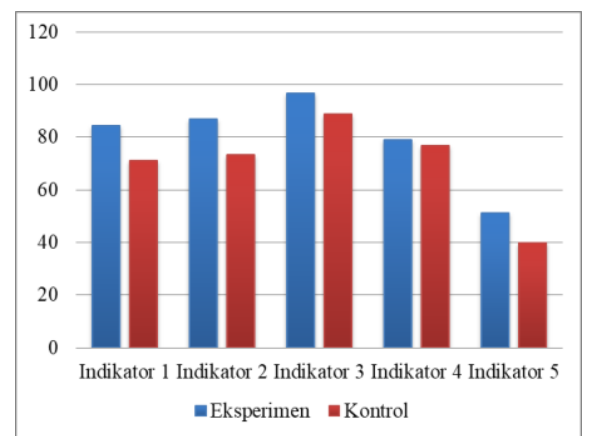

Figure 3. Bar Diagram of Mastery the concept score

Based on previous figures, there were significant differences in the posttest scores. These differences show that the mean of the students' mastery of the concept in the experimental class was higher than the control class.

The data of the pretest-posttest, tested using Independent T-Test, obtained a result of 0.001 or Sig (2-tailed) $<1 / 2 \alpha(\alpha=0.05)$. Based on the results, concluded that there is an effect of the learning model on the students' mastery of the concept. The calculation of Cohen's d effect size obtained a score of 0.949. Based on Cohen's criteria, this criterion has an effect of $51.6 \%$ and was included in the high category. In short, the implementation of this model has a high effect on the students' mastery of the concepts.

The advantage of the model of group investigation type in improving students' learning outcomes was, it facilitated the students to understand the difficult concepts. Isjoni (2013, p.83) states that the model can also train students to foster their ability to think analytically, critically, creatively, reflectively, and productively. So, students can find and well-mastery the concepts. Meanwhile, the advantage of outdoor learning systems was, students can establish more meaning or impressions of learning material in memory due to the learning process used subject matter directly (Haryanti, 2008).

Supported by Ayu et al. (2017), which states that there is an effect of the group investigation learning model with outdoor study nuances on the mastery of science competency in fourth-grade students in elementary school between the experimental group and the conventional learning group.

The Effect of Cooperative Learning Group Investigation Type with Outdoor Learning System Approach on Students' Problem-Solving Skill and Mastery of the Concept

MANOVA test was used to find out the effect of cooperative learning group investigation type 
with an outdoor learning system approach on students' problem-solving skills and mastery of the concept. The result of the MANOVA test showed a significant value of $0.032<0.05$. And, it concluded that there is a significant effect of the implementation of the cooperative learning group investigation type with an outdoor learning system approach on students' problem-solving skills and mastery of the concept.

Slavin (2005, p.215) argued that the model makes students able to interpret, evaluate observations, and identify what needs to be known and learned to master concepts and solve the problems through investigation. Moreover, those aim to train students to have knowledge with good group cooperation and solve the problems.

Husamah (2013) argues the outdoor learning approach has strengths, such as students will have fresh-thinking as the atmosphere changing, more productive in inquiry, more coherent exploration skills, and enrich the concept reinforcement. Moreover, Kellert (2002) states that students could gain problem-solving ability by implementing outdoor learning. Susilowati (2019, p.23) states, science learning with outdoor learning help to improve the students' problem-solving skills and cognitive learning outcomes.

This research was in line with Ayu (2016), which shows that there is a significant effect of the implementation of group investigation learning with an outdoor study on mastery of science competencies. The last, research by Rahmawan (2015) showed that learning outdoor mathematics in a group investigation with characters can improve problem-solving skills.

\section{CONCLUSION}

\section{Conclusion}

Based on the results and discussion, it concluded that the implementation of cooperative learning group investigation type with outdoor learning system approach provided the opportunity to improve problem-solving skills, namely the ability to identify, plan, test, and evaluate proper problem-solving methods and improve students' mastery of the concepts in Junior High School.

\section{Suggestion}

The article suggests that the teacher can apply the cooperative learning group investigation type with an outdoor learning system approach as a way and method to improve the students' problemsolving skills and mastery of the concept.

\section{REFERENCES}

Ayu, Gusti Putu A.K.D, et al. (2017). Pengaruh Model Pemebelajaran Goup Investigation Bernuansa Outdoor Study Terhadap Penguasaan Kompetensi Pengetahuan IPA Kelas IV. International Journal Elementary Education, 1(4), 316-324.

Becker, Lee. (2000). Effect Size (ES). Journal: Effect Size Measures for Two Independent Groups. Accessed on 5 May 2020 from http://web.uccs.edu/Ibecker/Psy590/es.htm.

Dewi, P,.R. (2012). Penerapan Model Group Investigation Terhadap Hasil Belajar Materi Bahan Kimia SMP. UNNES Science Education Journal, 1 (2).

Febria, N, et al. (2019). Pengaruh Model Pembelajaran Group Investigation Terhadap Kemampuan Pemecahan Masalah Siswa Kelas VIII MTSN Kabupaten Kerici. Journal Cendekia: Jurnal Pendidikan Matematika, 3 (2), 351-362.

Haryanti. (2008). Pembelajaran Pendidikan Luar Ruang. Jakarta: Kencana Prenada.

Husamah. (2013). Pembelajaran Luar Kelas Ourdoor Learning. Jakarta : Prestasi Pustaka

Insani, M, D. (2015). Studi Pendahuluan Identifikasi Kesulitan Dalam Pembelajaran Pada Guru IPA SMP Se-Kota Malang, Jurnal Pendidikan Biologi, 7 (2).

Isjoni. (2013). Pembelajaran Kooperatif Meningkatkan Kecerdasan Komunikasi Antar Peserta Didik. Yogyakarta: Pustaka Pelajar.

Kellert, S., R. (2002). Experiencing Nature: Affective, Cognitive, and Evaluative Development in Children.In P.H

Rahmawan, J. (2005). Model Pembelajaran Outdoor Mathematics dalam Group Investigation Bermuatan Karakter untuk Meningkatkan Kemampuan Pemecahan Masalah. UNNES Journal Mathematics Education Research, 4 (1).

Sastiawan, R, et al. (2019). Kemampuan Pemecahan Masalah pada Siswa Kelas X MA Suka Negeri Bengkulu Selatan Berbasis Lingkungan. PENDIPA Journal of Science Education, 3(1), 84-89.

Slavin, R.E. (2005). Coopeative Learning : Teori, Riset dan Praktik. Bandung : Nusa Penida.

Susilowati, et al. (2019). Development the Sciences Outdoor Learning to Improve Knowlede Competences and Problem Solving Skills of Junior High Scholl Students. Prosiding, International Conference on Research, Implementation and Education of Mathematics and Sciences on 13 July 2019 in UNY. Yogyakarta: Universitas Negeri Yogyakarta.

Vera, A. (2012). Metode Mengajar Anak di Luar Kelas (Outdoor Study). Yogyakarta : DIVA Press. 